\title{
Development of Oral Communicative Competence: A Teachers' Perspective
}

\author{
Dr. Syeda Naureen Mumtaz*, Dr.Uzma Quraishi**
}

\begin{abstract}
This study was an attempt to determine the point to which the English language textbook, "English for Class 8" prescribed by the Punjab Textbook Board fulfills the learners language learning needs of English as foreign language in Pakistan. The study aimed to explore as to what degree the suggested textbook increases the likelihood of learning the language and the diligent effort to development oral communicative competence (OCC) among the target learners. A quantitative approach enabled the researcher to comprehensively answer the research question, and data was collected using a questionnaire. Questionnaire's each item was developed keeping in view the research question and its objective. For this purpose, forty English language teachers were selected from public sector schools. Descriptive statistics was used for data analysis and the results were presented in figures. The results indicate that the relevant course book fails to facilitate the target learners to acquire English as foreign language to enable them to use the language for communicative purposes. The tasks presented in the textbook, do not focus on sociolinguistic and extended verbal expression in speech of the target language. By including tasks that challenge the learners to engage themselves in producing meaningful utterances, the present English language textbook can become even better a tool to develop speech proficiency.
\end{abstract}

Key words: Evaluation, Language acquisition, Speech proficiency

This Article can be cited as:

Mumtaz S N., Quraishi U., (2020). Development of Oral Communicative Competence: A Teachers' Perspective, Journal of Arts and Social Sciences. VII (2), 199-216.

\footnotetext{
* Correspondence concerning this article should be addressed to Dr. Syeda Naureen Mumtaz, Assistant Professor, University of Education Lahore, Pakistan, Sagitarius437@yahoo.com.

** Professor Dr. Uzma Quraishi, Vice Chancellor, Women University Multan, Pakistan, uzmaqr69@gmail.com.
} 


\section{Introduction}

Textbook is a significant artifact in educational landscape; the researcher believes that in Pakistan, teachers' community solely bank on textbook, so there is a need to develop a textbook which caters to the diverse language learning needs of the students to equip them with a lifelong skill; by developing oral communicative competence among the target learners.

In Pakistan attempts have been made to evaluate English language textbooks taught at different levels with different perspectives, however, a language textbook used in public schools at grade VIII level, primarily to assess learners' oral communicative competence in English language has not yet been attempted, therefore, the present study is expected to contribute to language skills as well as oral communicative competence development.

The researcher has drawn from her teaching experience that students may possess grammatical competence or in some cases strategic competence, however, they lack overall ability to use language in speech. Being competent implies knowing more than the language structures; it also refers to being able to interact socially in the target language. The researcher's belief led to a usefulness of investigating the teachers' perception about the target textbook to examine how far the content is relevant to the social communicative purposes and functions, and not merely based on linguistic structures. In this case, textbook presenting various activities focusing on target learners' speech proficiency is a significant variable, and its effectiveness is being measured in the present study.

Dornyel \& Thurell (1991) report that above everything else, traditionally language classrooms aim at developing grammatical competence. The result of all this is that learners after acquiring vocabulary, grammar and pronunciation for a long time, are still unable to communicate effectively (Cohen, 2011).

\section{Statement of the Problem}

The study intends to determine the effectiveness of the current textbook with a special reference to English acquired as foreign language and more importantly, development of OCC. Like any other developing country, teachers in Pakistan, depend on the textbook to a large extent. It is therefore, needed to measure the quality of the recommended textbook in terms of OCC development, it implies that there is an enormous number of grade VIII learners who may get affected as result of studying the prescribed textbook. Therefore, it is only essential to look into the effectiveness of the said textbook used to develop OCC among grade VIII learners.

\section{Objective of the Study}

The researcher wanted to seek the perceptions of the teachers about an overall effectiveness of the English language textbook regarding speech proficiency.

\section{Research Question}

How far has the current English language textbook been effective to achieve the desired language development leading to oral communicative competence?

\section{Significance of the Study}

Research findings of the present study will help to modify the exiting English language textbook and the activities presented in it for better oral communicative competence development, and to help learners acquire English as foreign language in Pakistan. The study will also provide a direction for inservice teacher training institutes and policy. Also, a general strategy for effective teaching to develop communicative competence (CC) will emerge to help a wide array of teachers, policy makers, and theorists 
to develop their study of communicative competence and the role of textbooks in assisting language acquisition and CC.

\section{Evaluation}

Textbooks' important role in teaching English as foreign language is irrefutable, as it provides a useful ready to teach material to teachers. However, incongruous course books may hamper the skills of teachers and their students. Lee (2013) values teaching resource material as a good option for imparting language input. Literature considers this appraisal as an important activity to provide a basis for developing new textbooks. Classroom language teaching usually takes place with the help of the materials chosen, which in most cases, is the textbook and teachers base their practice on what the textbook proposes (Tomlinson, 2008). Hence, it is necessary to examine the prescribed English language textbook materials' potential in terms of skill and communicative competence development.

\section{Language Acquisition}

Derakhshan, et al (2015) advocates that foreign language education is more about the development and production of speaking skill, which did not receive much attention in the past. Language production is precisely the ability of students to be able to write and speak, without any incomprehensibility in the target language. Similarly, researchers (Fang \& Zhang, 2017) claimed that maintaining meaningfulness in spoken language is required in different contexts. A review of literature also demonstrates that nowadays the focus of language learning is on communicative competence, rather than linguistic competence. The current foreign language education emphasizes on language production and development of speaking skill has received much attention in the past four decades (Derakhshan et al., 2015).

\section{Speech Proficiency(SP.)}

The idea of performance is linked with competence (Chomsky, 1960s). For some linguists (Campbell \& Wales, 1970; Hymes, 1972) performance is more about production of language appropriate to a context. Likewise, Saleh (2016) argues that linguistically, SP. refers to the speaker's ability to use befitting language in the appropriate setting for its right interpretation. For Canale \& Swain (1980), Bachman \& Palmer (1996), the ability to communicate properly is not stagnant but kinetic, not intrapersonal but social and unlimited rather than limited. The concept of communicative competence presented by Canale \& Swain $(1980,1983)$ is a broader concept which is based on their theory that competence involves more than knowing the language rules and structures. According to this theory the primary function of language is communication and interaction. The study, primarily subscribes to one of the popular theories presented by Canale \& Swain $(1980,1983)$.

\section{Research Methodology}

The present study is a quantitative research by method, like all interpretive studies, in the present study also the researcher attempted to make sense of the phenomena in terms of how respondents look at the facts and interpret them (Stein et al., 2012). The researcher has used a questionnaire to highlight the breadth and depth of beliefs and practices of the English language teachers as related to textbook precisely.

The research tool consisted of 17 closed ended questions, these questions focused on as how effective is the current textbook in terms of language skills development, with a special reference to OCC development. A five point Likert scale questionnaire was used to measure the response of the respondents of the study. 


\section{Population}

The quantitative study consisted of a population spread over 20 schools in the North and Center region of the province of Punjab. Forty male and female teachers, teaching at grade VIII level in the target schools were selected from the target areas.

\section{Sampling Technique}

The researcher has applied simple random sampling, because it is least biased; and the technique which is used is cluster random sampling because when the population is homogeneous, and spread over a vast region, it is most desirable to divide it in to clusters (Mackey \& Gass, 2007).

\section{Research Instrument and its Validity}

Questionnaires are effective to collect a wide range of data (Kumar, 2010; Bryman, 2008; \& Lodico et al., 2010). In the present study, the researcher preferred devising her own questionnaire to provide her with the most relevant data. A questionnaire was designed for the language teachers to get their responses about the present textbooks as how much helpful the present textbook is in teaching language to grade VIII learners. A pilot study was conducted to improve the questionnaire. Finally, the modified version of questionnaire was used in collecting the final data.

The validity and reliability of the research tool was ensured through pilot testing and expert opinion. Cronbach's alpha reliability test was run on the teachers' questionnaire results through SSPS, showing.857 which indicates a high level of internal consistency of the scale.

\section{Data Collection}

Walliman (2016) argues that there are four types of primary data collection procedures; "observation, participation, measurement and interrogation" .In the present study the primary data is gathered through questionnaire. Books, journals and articles have provided the secondary data for the present study.

\section{Data Analysis and Findings of the Study} the Punjab

Questionnaire Response Analysis of Male and Female Teachers from Center and North Region of

Statement 1. Do you teach the entire textbook with all its activities and exercises?

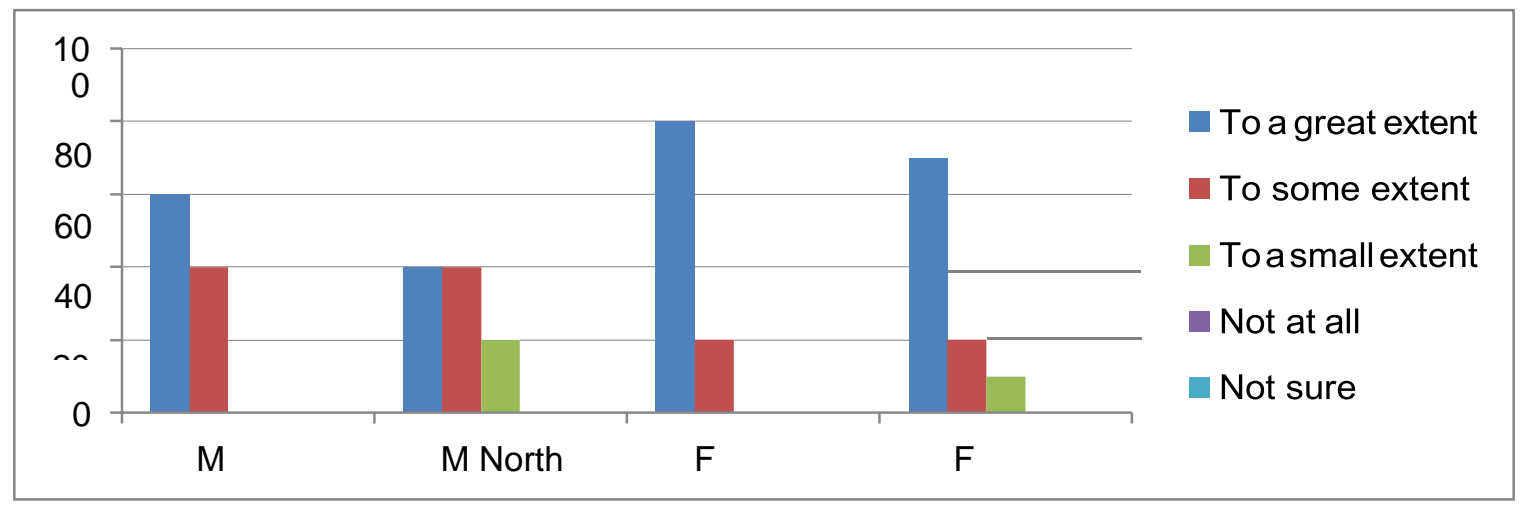




\section{Figure 1}

Teaching the entire textbook is very important for students as it is linked to the next higher level. This research shows that $60 \%$ of male teachers from center region of the Punjab are able to do so to a great extent, $40 \%$ of them could teach to some extent. In the north region $40 \%$ are performing it to a great extent, $40 \%$ to some extent and $20 \%$ to a small extent. On the female side of center region $80 \%$ are able to finish the textbook to a great extent and $20 \%$ are doing so to some extent. In the north region $70 \%$ are completing the entire textbook teaching, $20 \%$ could finish textbook to some extent and $10 \%$ to a small extent. The above picture clearly shows that female teachers from center and north region are performing better than their male colleagues in the respective regions.

Statement 2. To what extent are you satisfied with the prescribed textbook in terms of developing "listening skills"?

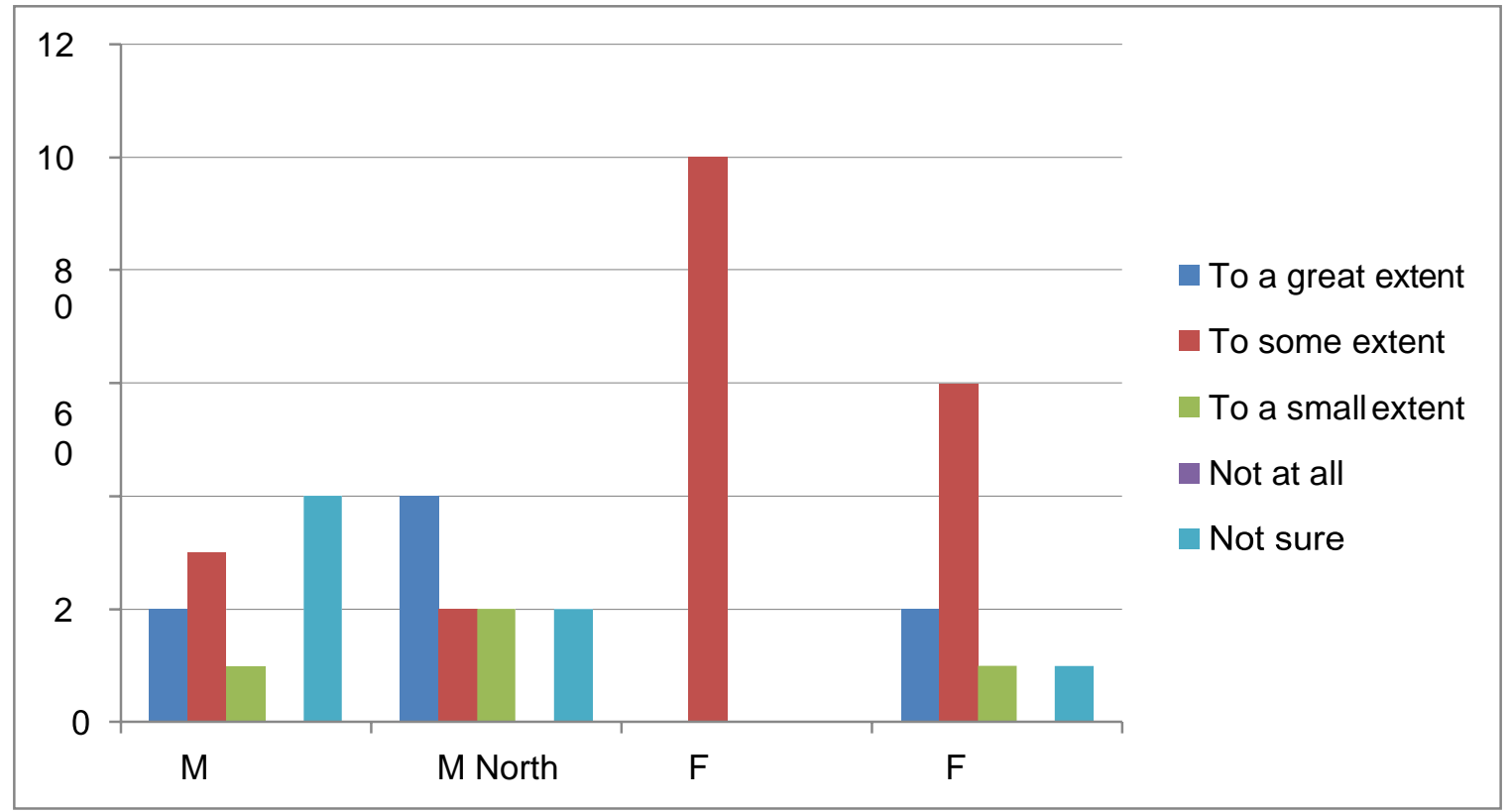

Figure 2

Only $20 \%$ of the male teachers from center region, $40 \%$ from north region, and $20 \%$ of the female teachers from north region said that the textbook helped students to develop their listening skills to a great extent. $30 \%$ of male teachers from center region, $20 \%$ from north region, $100 \%$ of the female teachers from center region, $60 \%$ from north region said that textbook helped to improve listening skills to some extent. $10 \%$ of male teachers from center region, $20 \%$ from north region and $10 \%$ of female teachers from north region believed that it did help improve listening skills to a small extent.40\% of male teachers from center region, $20 \%$ from north region, $10 \%$ of female teachers from north region said they are not sure of any role of the textbook in developing listening skills.

Statement 3. To what extent are you satisfied with the prescribed textbook in terms Of developing speaking skills? 


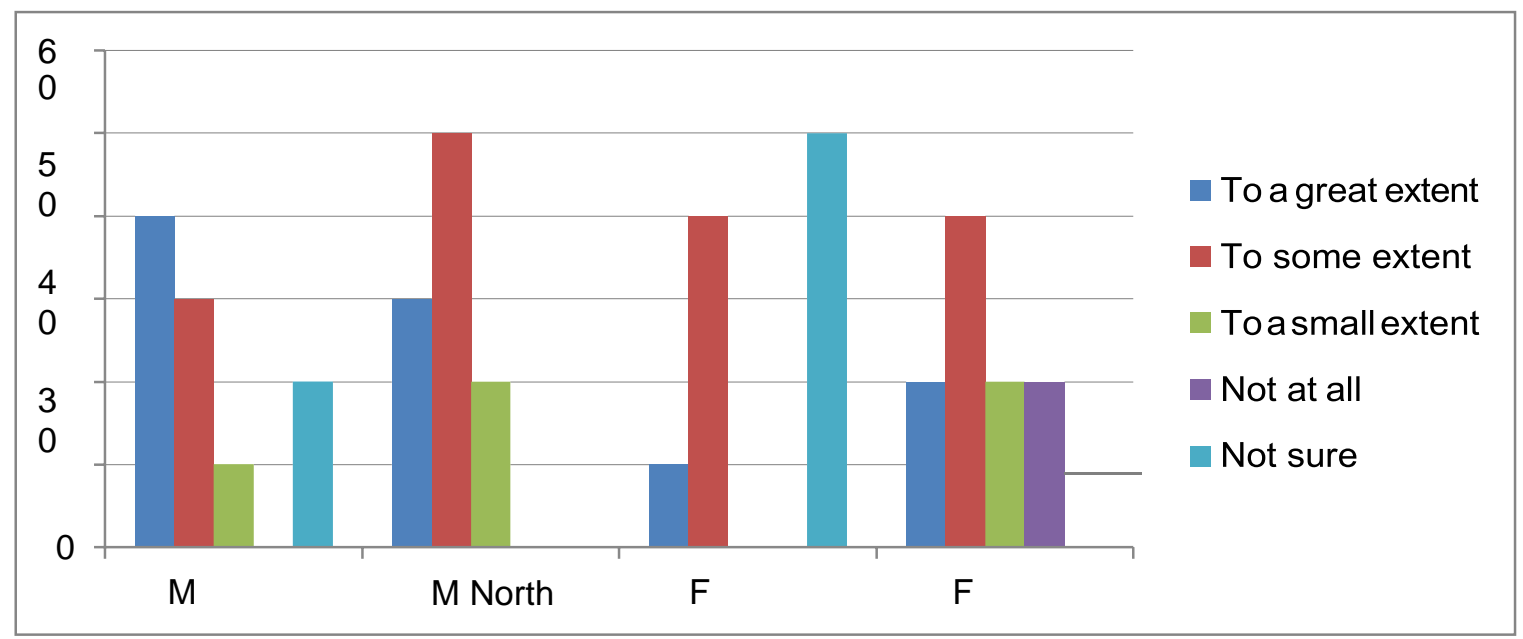

Figure 3

Forty percent of male teachers from center, $30 \%$ from north, $10 \%$ of female teachers from center and $20 \%$ from north region believed that textbook helped to develop speaking skills to a great extent. $30 \%$ of male teachers from center, $50 \%$ from north, $40 \%$ of female teachers from center and $40 \%$ from north region reflected that textbook did so to some extent. $10 \%$ of male teachers from center, $20 \%$ from north , none of the female teachers from center and $20 \%$ from north region were of the opinion that textbook was useful in developing speaking skills to a small extent. 20\% Female teachers from north region were the only one who thought that textbook was not helpful at all in developing speaking skills. $20 \%$ of male teachers and $50 \%$ of female teachers from center region showed that they were not sure about the textbook helping students to develop speaking skills.

Statement 4. To what extent are you satisfied with the prescribed textbook in terms of developing reading skills?

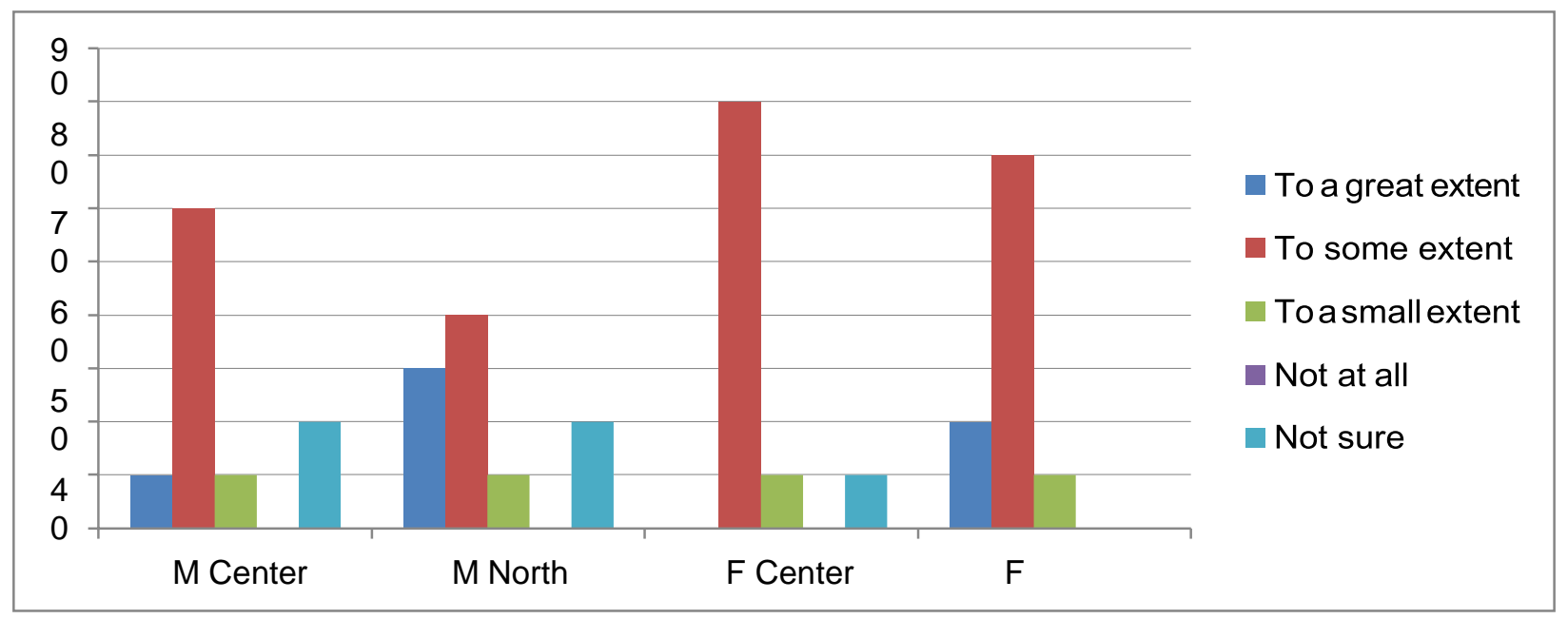




\section{Figure 4}

Ten percent of male teachers from center, $30 \%$ from north and $20 \%$ of female teachers from north region recorded their opinion that textbook was helpful in developing reading skills to a great extent. $60 \%$ of male teachers from center, $40 \%$ from north, $80 \%$ of female teachers from center and $70 \%$ from north region said the textbook was useful in developing reading skills to some extent. $10 \%$ of male and female teachers from all regions said that textbook is helpful in developing reading skills to a small extent. $20 \%$ of male teachers from each region and $10 \%$ of female teachers from center region said that they were not sure about its benefit for developing reading skills.

Statement 5. To what extent are you satisfied with the prescribed textbook in terms of developing writing skills?

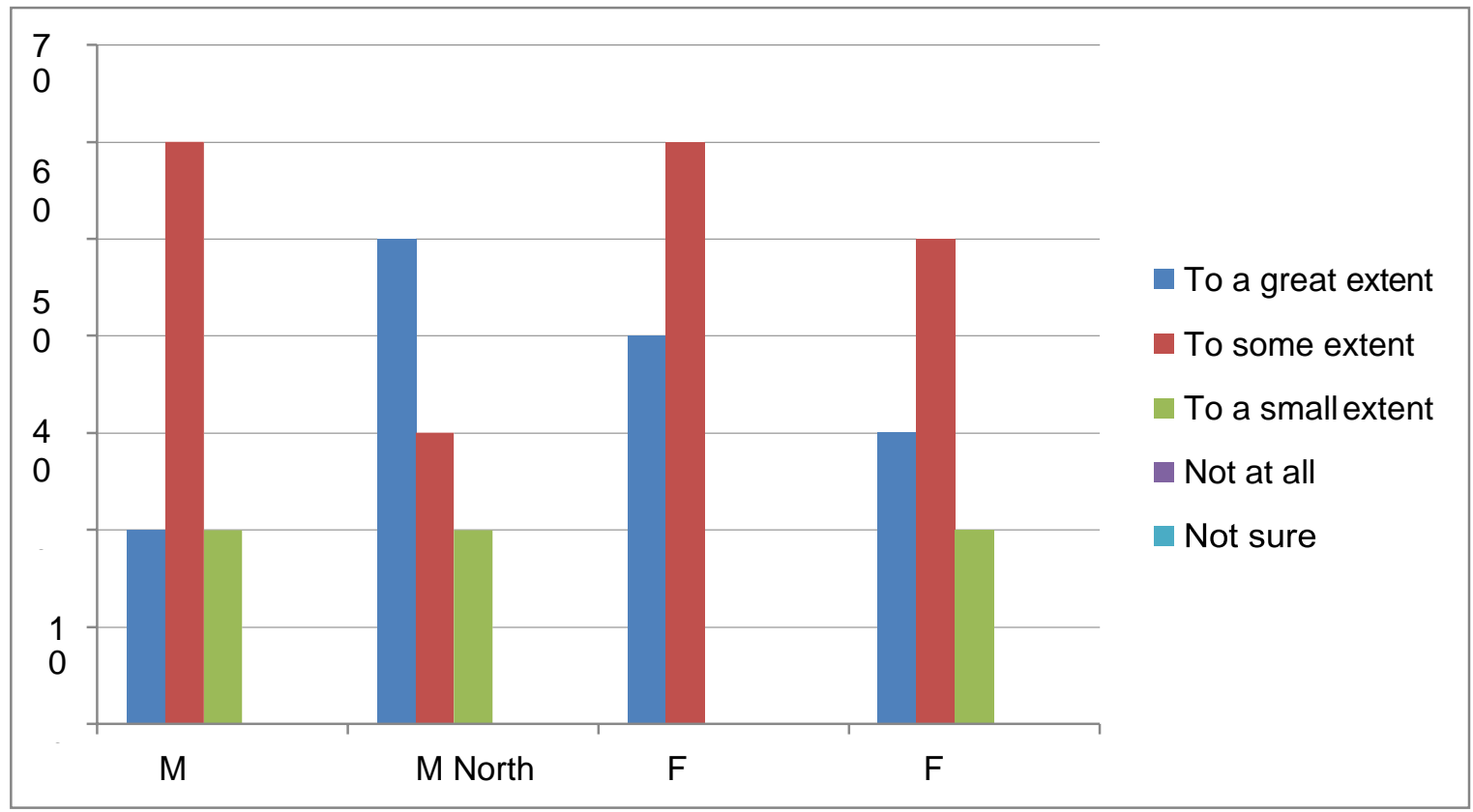

Figure 5

Twenty percent of male teachers from center, $50 \%$ from north, $40 \%$ of female teachers from center and $30 \%$ from north region believed the textbook to be good for improving writing skills to a great extent. $60 \%$ of male teachers from center, $30 \%$ from north, $60 \%$ of female teachers from center and 50\% from north region reflected that textbook was helpful in developing writing skills to some extent. $20 \%$ of male teachers from each region and $20 \%$ of female teachers from north region say that textbook is useful for developing writing skills to a small extent.

Statement 6. To what extent the topics used in the textbook are age appropriate (according to learner's age)? 


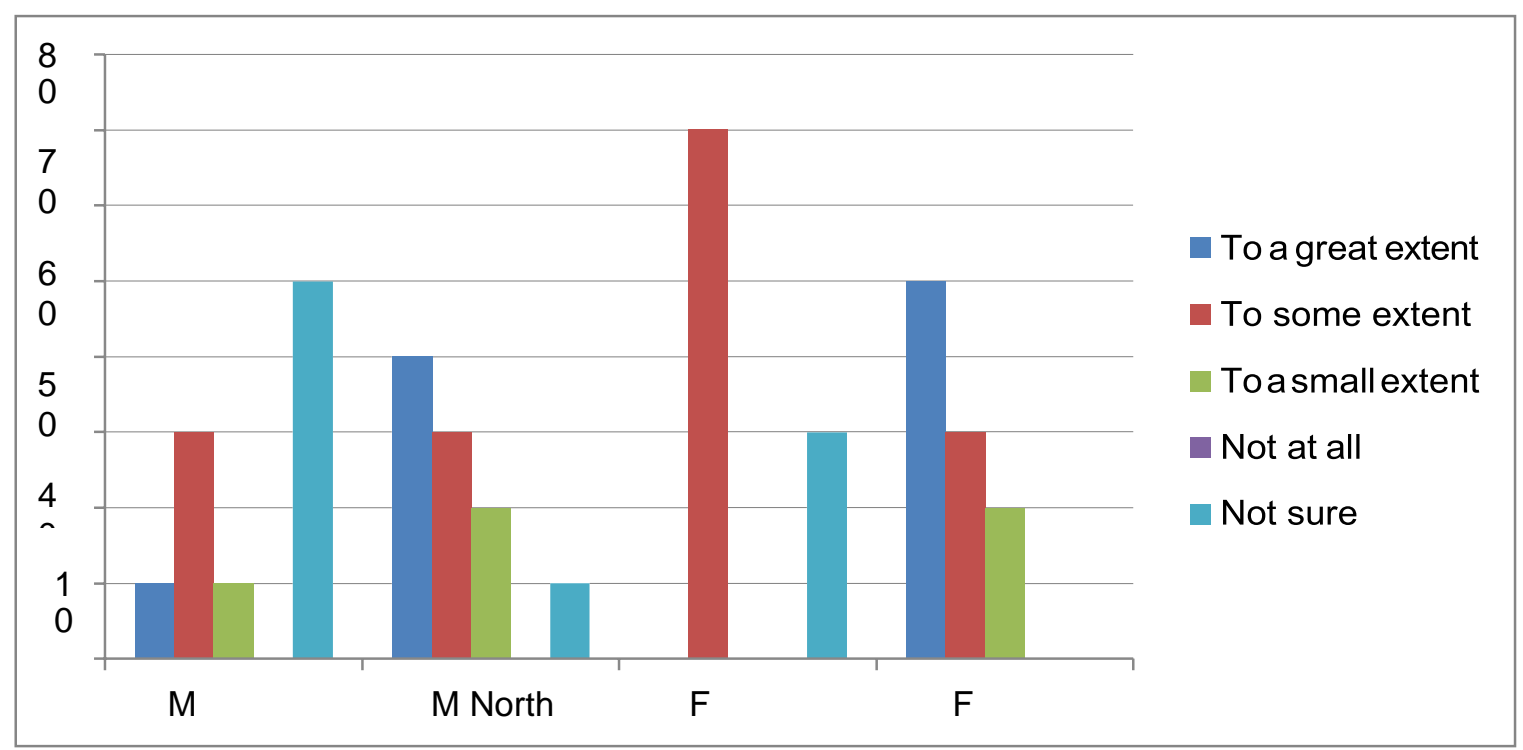

Figure 6

Ten percent of the participating male teachers from center, $40 \%$ from north and $50 \%$ of the female teachers from north region said that textbook topics were age appropriate to a great extent. $30 \%$ of male teachers from center and north each, $70 \%$ of female teachers from center and 30\% from north region said that textbook topics were age appropriate to some extent. $10 \%$ of male teachers from center, $20 \%$ from north and $20 \%$ of female teachers from north region thought that topics were so to a small extent while $50 \%$ of male teachers from center, $10 \%$ from north and $30 \%$ of female teachers from center region said they were not sure about topics of the textbook being age appropriate or not.

Statement 7. To what extent vocabulary used in the textbook is age appropriate?

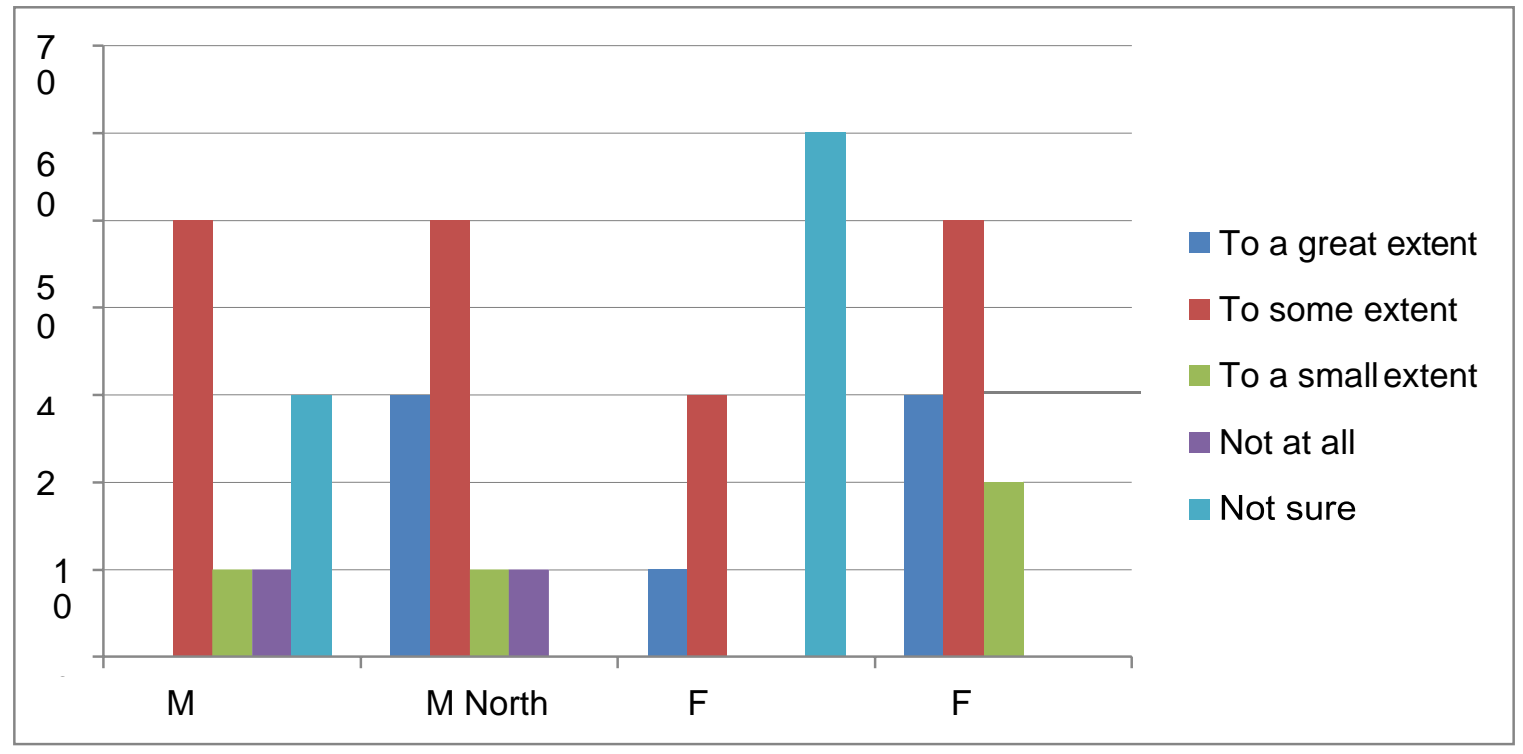




\section{Figure 7}

Thirty percent of male teachers from north, $10 \%$ of female teachers from center and $30 \%$ from north region said that textbook vocabulary was age appropriate to a great extent. 50\% of the male teachers from center, $50 \%$ from north, $30 \%$ of female teachers from center and 50\% from north region reflected that vocabulary used in the textbook was age appropriate to some extent. $10 \%$ of male teachers from center, north and $20 \%$ of female teachers from north regions said it was so to a small extent. $30 \%$ of male teachers from center and $60 \%$ of female teachers from center region were not sure about this.

Statement 8.To what extent do the activities help learners pronounce words accurately?

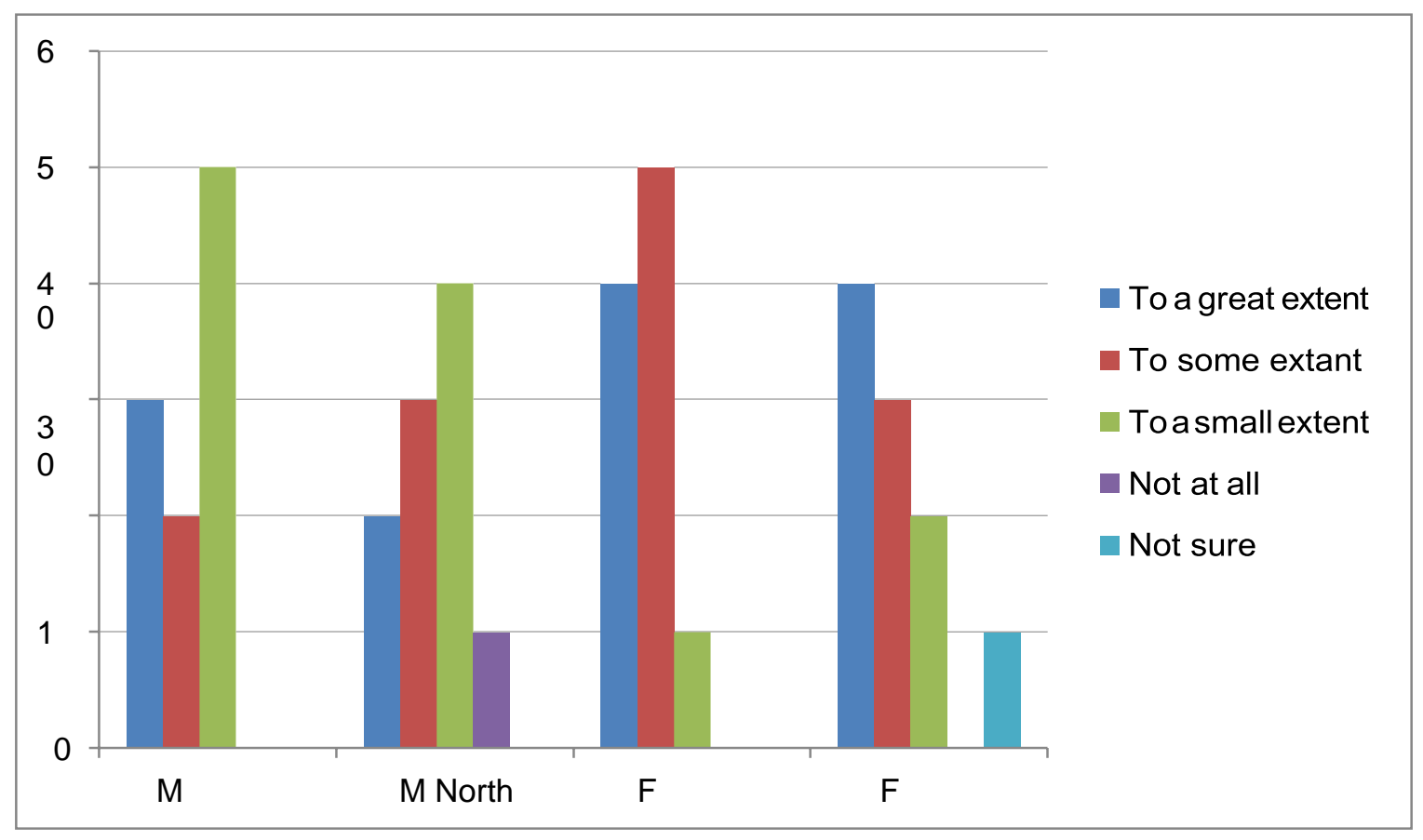

\section{Figure 8}

Thirty percent of male teachers from center, $20 \%$ from north, $40 \%$ of female teachers from center and north region each believed that activities in the textbook helped learners pronounce words accurately to a great extent. $20 \%$ of male teachers from center, $30 \%$ from north, $50 \%$ of female teachers from center and $30 \%$ from north region had opinion that activities in the textbook help learners pronounce words accurately to some extent. $50 \%$ of male teachers from center, $40 \%$ from north, $10 \%$ of female teachers from center and $20 \%$ from north region said activities in the textbook help learners pronounce words accurately to a small extent. $10 \%$ of male teachers from north region say activities in the textbook not at all help learners pronounce words accurately. $10 \%$ of female teachers from north region said that they are not sure whether activities help learners pronounce words accurately or not.

Statement 9. To what extent the textbook is based on the learner's needs? 


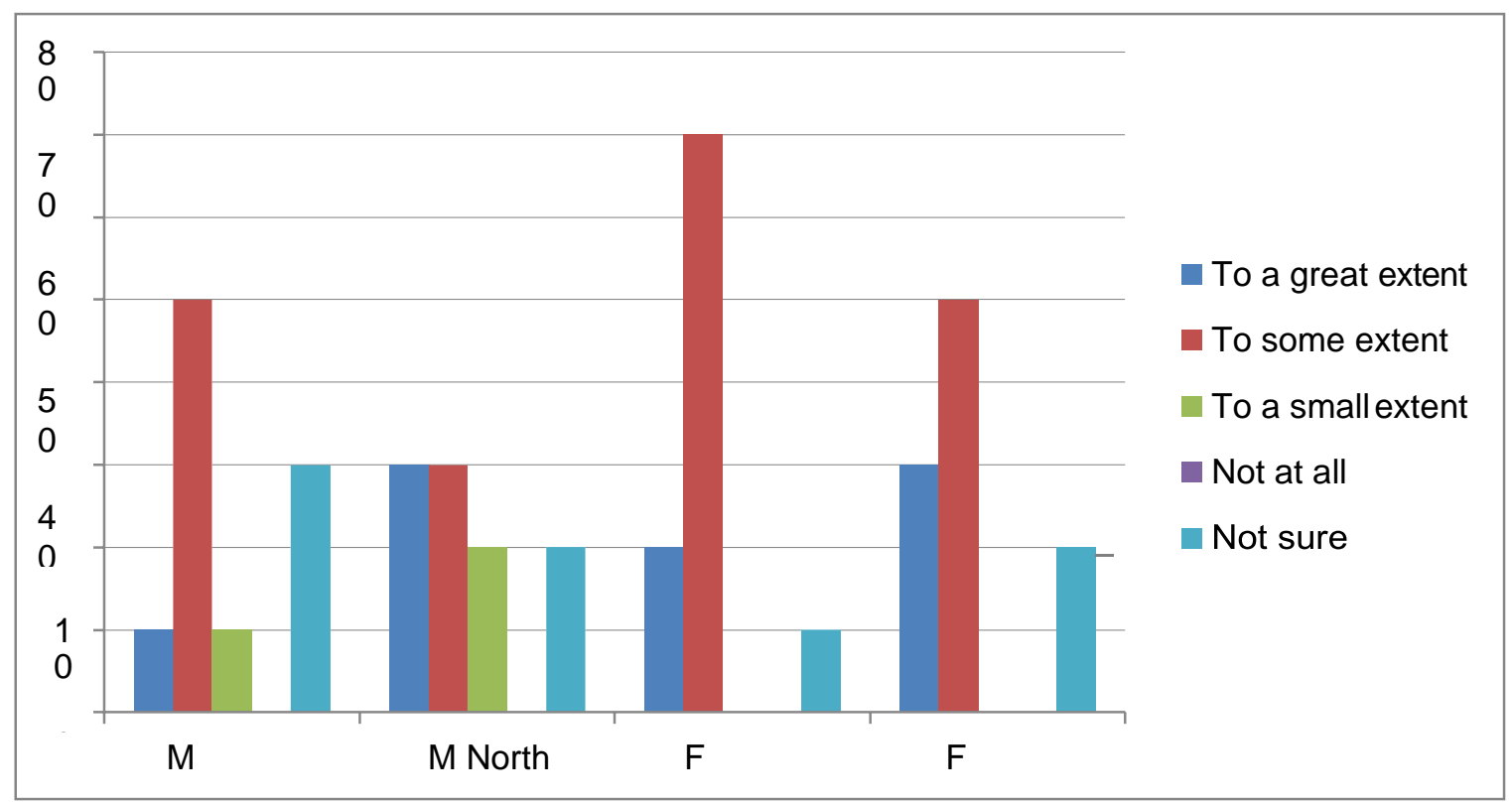

Figure 9

Ten percent of male teachers from center, $30 \%$ from north, $20 \%$ of female teachers from center and $30 \%$ from north region recorded that textbook was based on the learner's needs to a great extent. $50 \%$ of male teachers from center, $30 \%$ from north, $70 \%$ of female teachers from center and $50 \%$ from north region said that textbook catered needs of learners to some extent. $10 \%$ of male teachers from center and $20 \%$ from north region said that textbook was according to the learners needs to a small extent. $30 \%$ of male teachers from center, $20 \%$ from north, $10 \%$ of female teachers from center and $20 \%$ from north region said that they are not sure about it.

Statement 10. How far do the activities help students to think creatively?

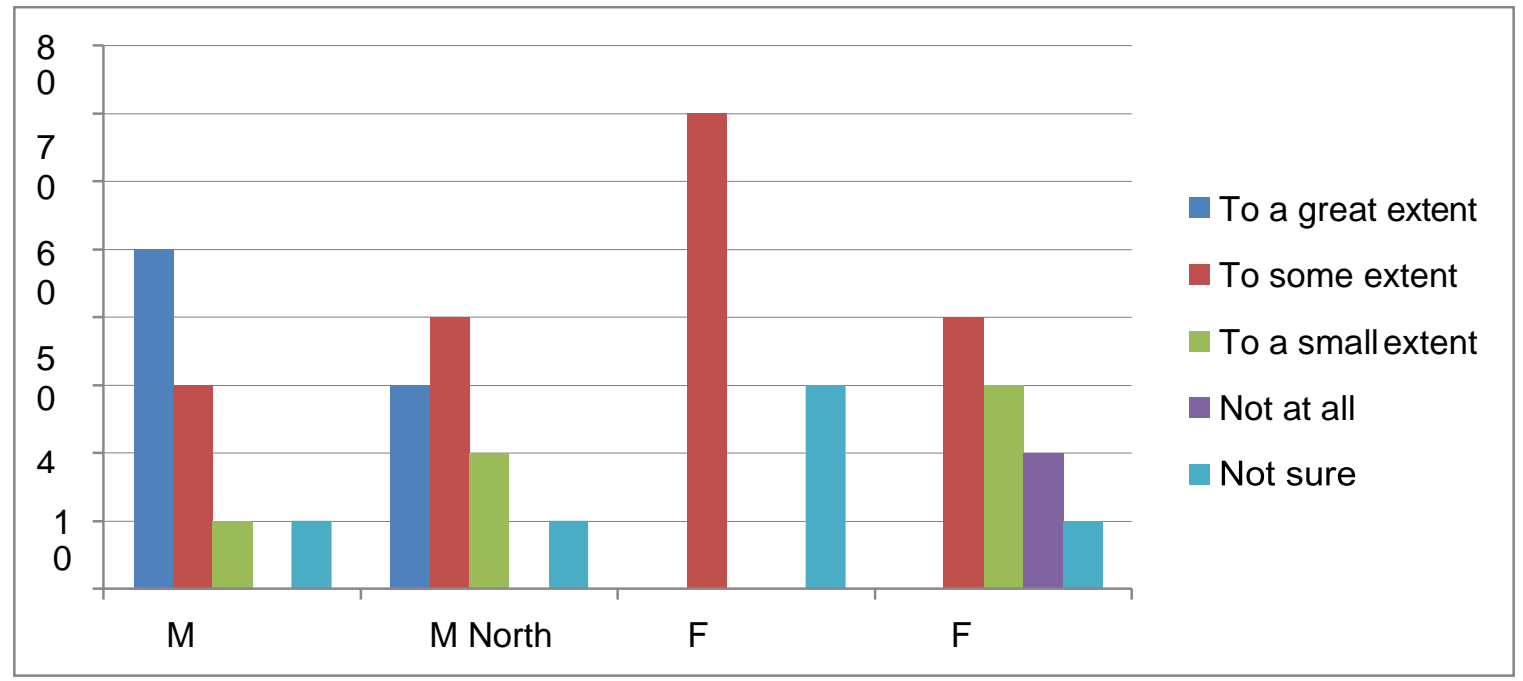




\section{Figure 10}

Fifty percent of male teachers from center and 30\% from north region said that activities in the textbook did help students think creatively to a great extent while female teachers from both regions disagreed with them. $30 \%$ of male teachers from center, $40 \%$ from north, $70 \%$ of female teachers from center and $40 \%$ from north region said that activities in the textbook did help students to think creatively to some extent. $10 \%$ of male teachers from center, $20 \%$ from north and $30 \%$ of female teachers from north region had opinion that it is so to a small extent. Only $20 \%$ of female teachers from north think that activities in the textbook did not at all help students to think creatively. $10 \%$ of male teachers from center, $10 \%$ from north, $30 \%$ of female teachers from center and $10 \%$ from north said they were not sure about it.

Statement 11. Does the textbook contain a variety of tasks to help improve learner's communicative competence?

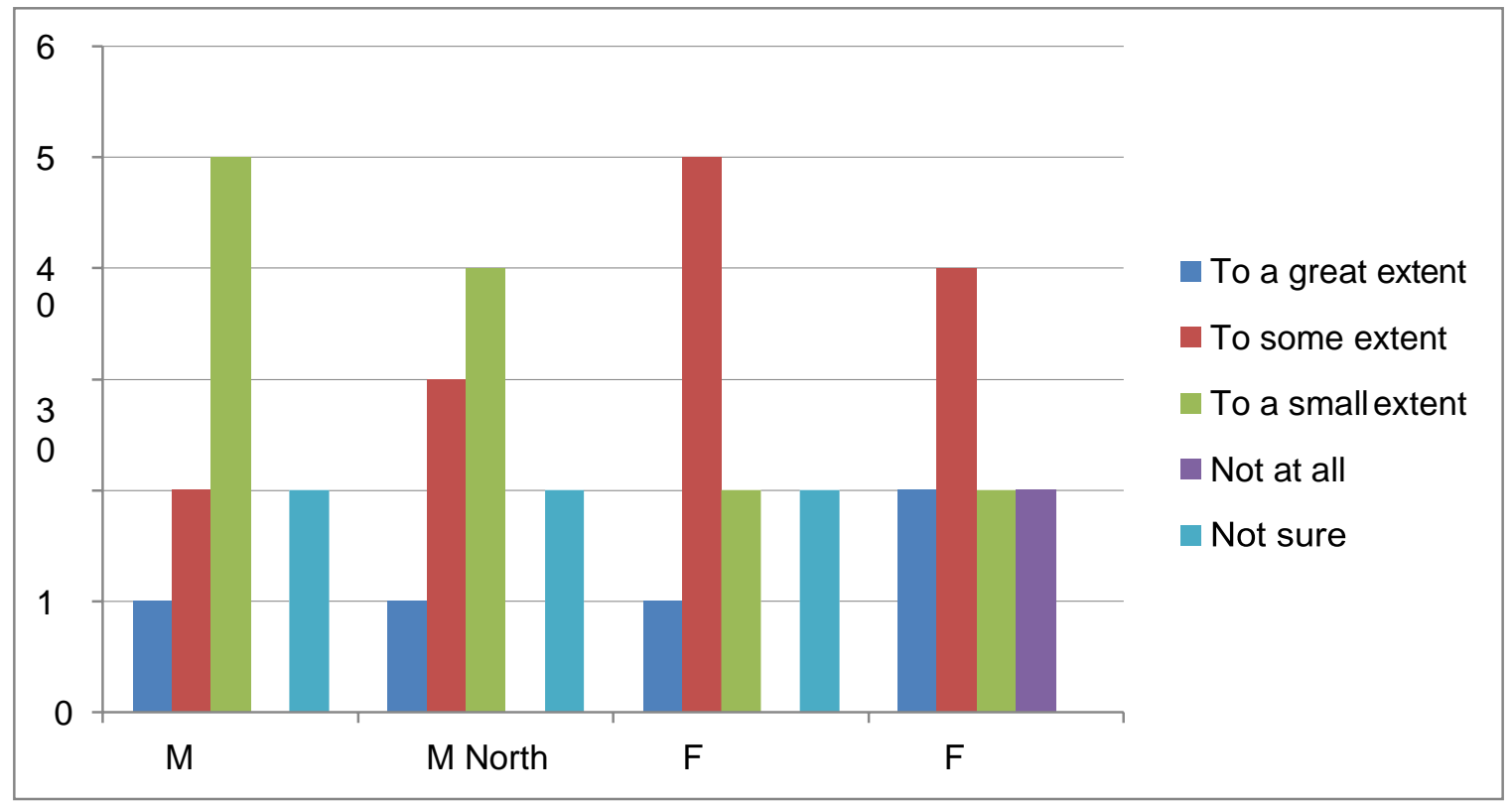

Figure 11

Ten percent of male teachers from center, north, $10 \%$ of female teachers from center and $20 \%$ from north region said textbook did improve learner's communicative competence to a great extent. $20 \%$ of male teachers from center, $30 \%$ from north, $50 \%$ of female teachers from center and $40 \%$ from north region said it was so to some extent. $50 \%$ of male teachers from center, $40 \%$ from north, $20 \%$ of female teachers from center and north region each said that it was so to a small extent. Only $20 \%$ of female teachers from north region said that tasks given in the textbook did not improve learner's communicative competence at all. $20 \%$ of male teachers from center, north each and $20 \%$ of female teachers from center region said they are not sure about it. 
Statement 12. To what extent do the learners find the prescribed textbook easy to understand (teacher does not have to translate in Urdu)?

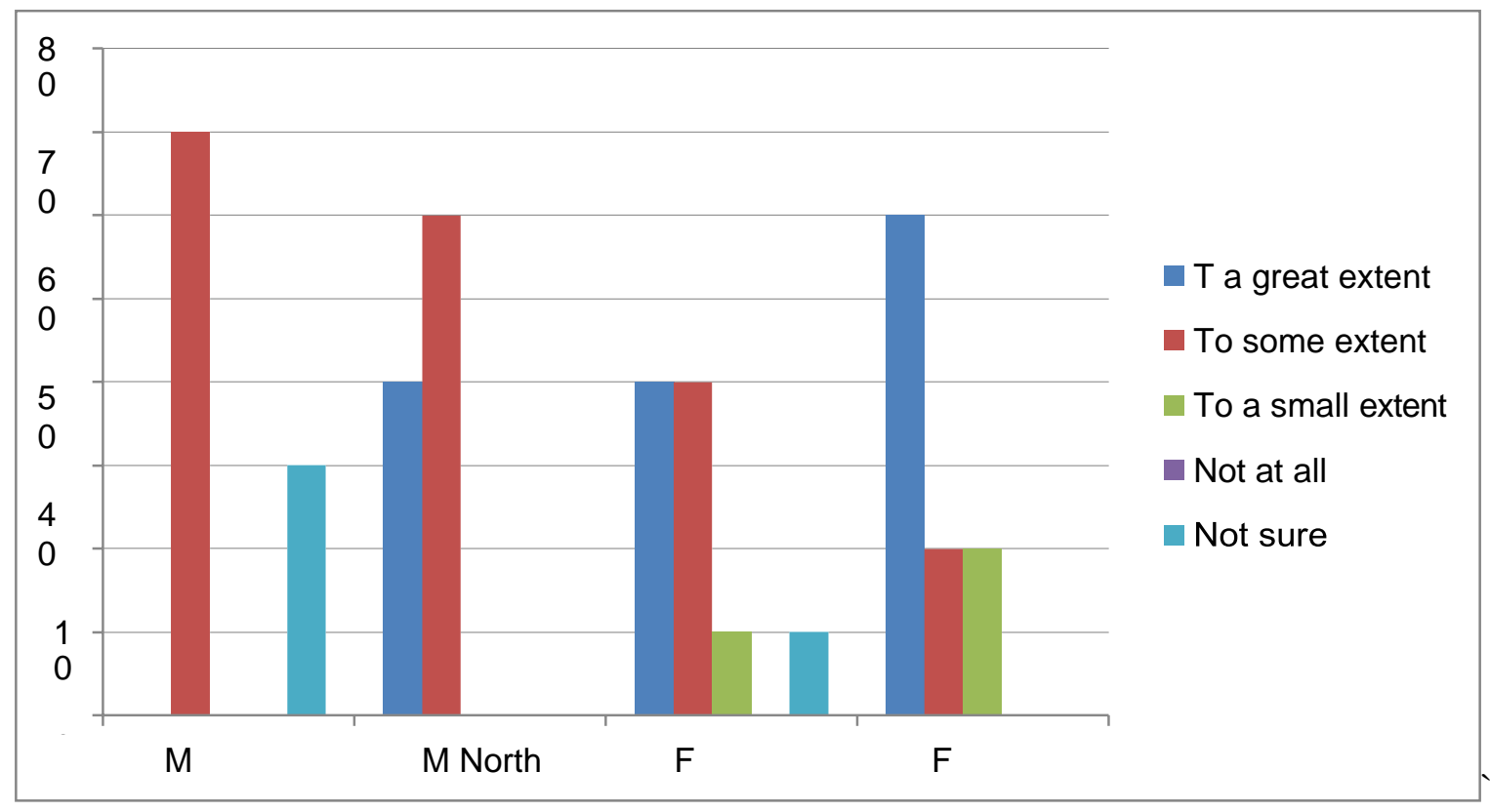

\section{Figure 12}

Forty percent of male and female teachers from north, center respectively and $60 \%$ of female teachers from north region said that learners found textbook easy to understand to a great extent. $70 \%$ of male teachers from center, $60 \%$ from north, $40 \%$ of female teachers from center and $20 \%$ from north region felt that it was so to some extent. Only $10 \%$ of female teachers from center and $20 \%$ from north region reflected the opinion that it is so to a small extent while $30 \%$ of male teachers from center region said they were not sure about it.

Statement 13. To what extent has the level of English of your students improved after using the prescribed textbook?

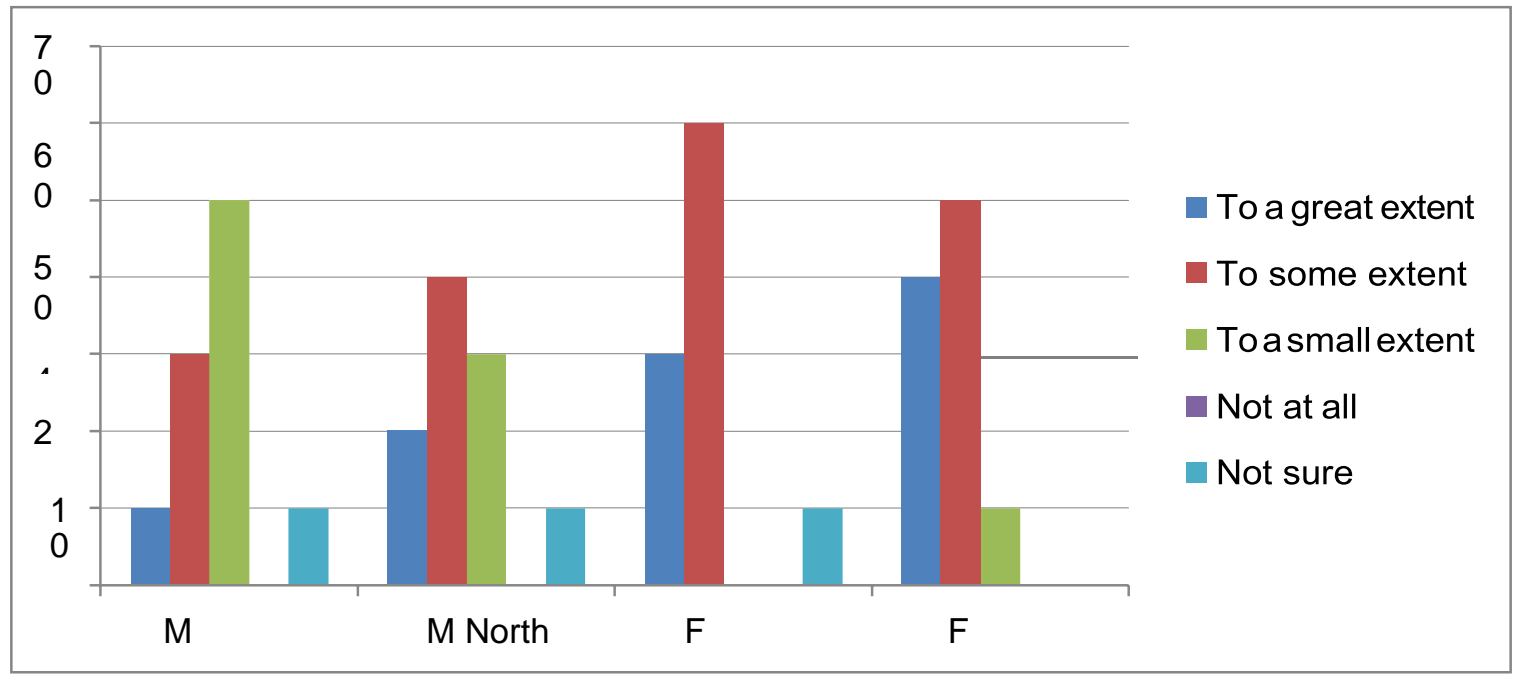




\section{Figure 13}

Ten percent of male teachers from center, $20 \%$ from north, $30 \%$ of female teachers from center and $40 \%$ from north region said that because of the prescribed textbook, level of English had been improved to a great extent. $30 \%$ of male teachers from center, $40 \%$ from north, $60 \%$ of female teachers from center and $50 \%$ from north region said that it is so to some extent. $50 \%$ of male teachers from center, $30 \%$ from north and $10 \%$ of female teachers from north region believed that it was so to a small extent. $10 \%$ of male teachers from center, north each and $10 \%$ of female teachers from center region said that they were not sure about it.

Statement 14. To what extent does the textbook promote learners to speak in English?

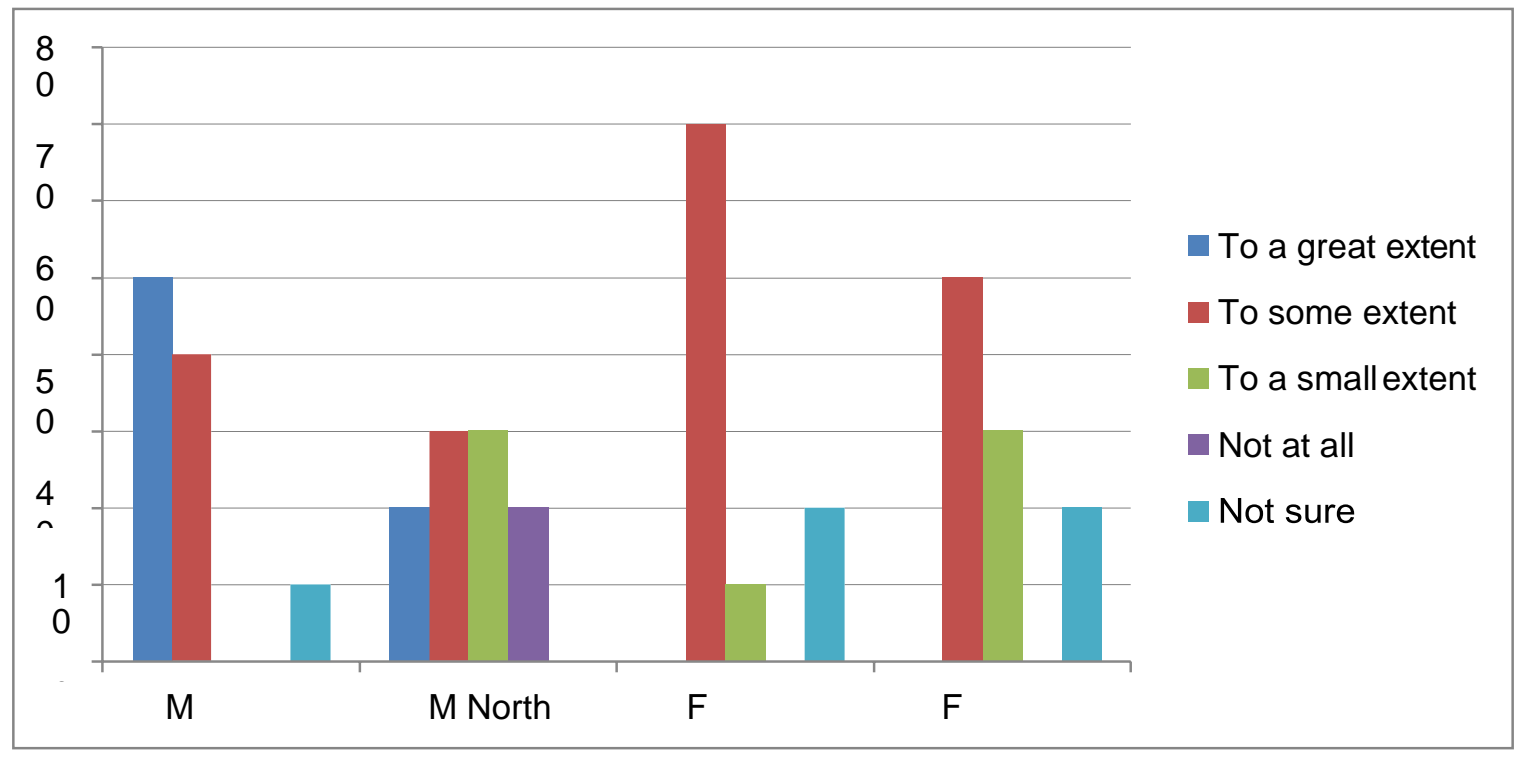

Figure 14

This research reveals that $50 \%$ of male teachers from center and $20 \%$ from north region believed that textbook promoted learners to speak in English to a great extent while all the female teachers disagreed with them. $40 \%$ of male teachers from center, $30 \%$ from north, $70 \%$ of female teachers from center and $50 \%$ from north region said that it is so to some extent. $30 \%$ of male teachers from north, $10 \%$ of female teachers from center and $30 \%$ from north region had opinion that it was so to a small extent. Only $20 \%$ of male teachers from north region said textbook not at all promote learners to speak in English. 10\% of male teachers from center, $20 \%$ of female teachers from center and north region each said that they are not sure about it.

Statement 15. To what extent do activities (offered in textbook) provide an opportunity to learners to interact with each other in English? 


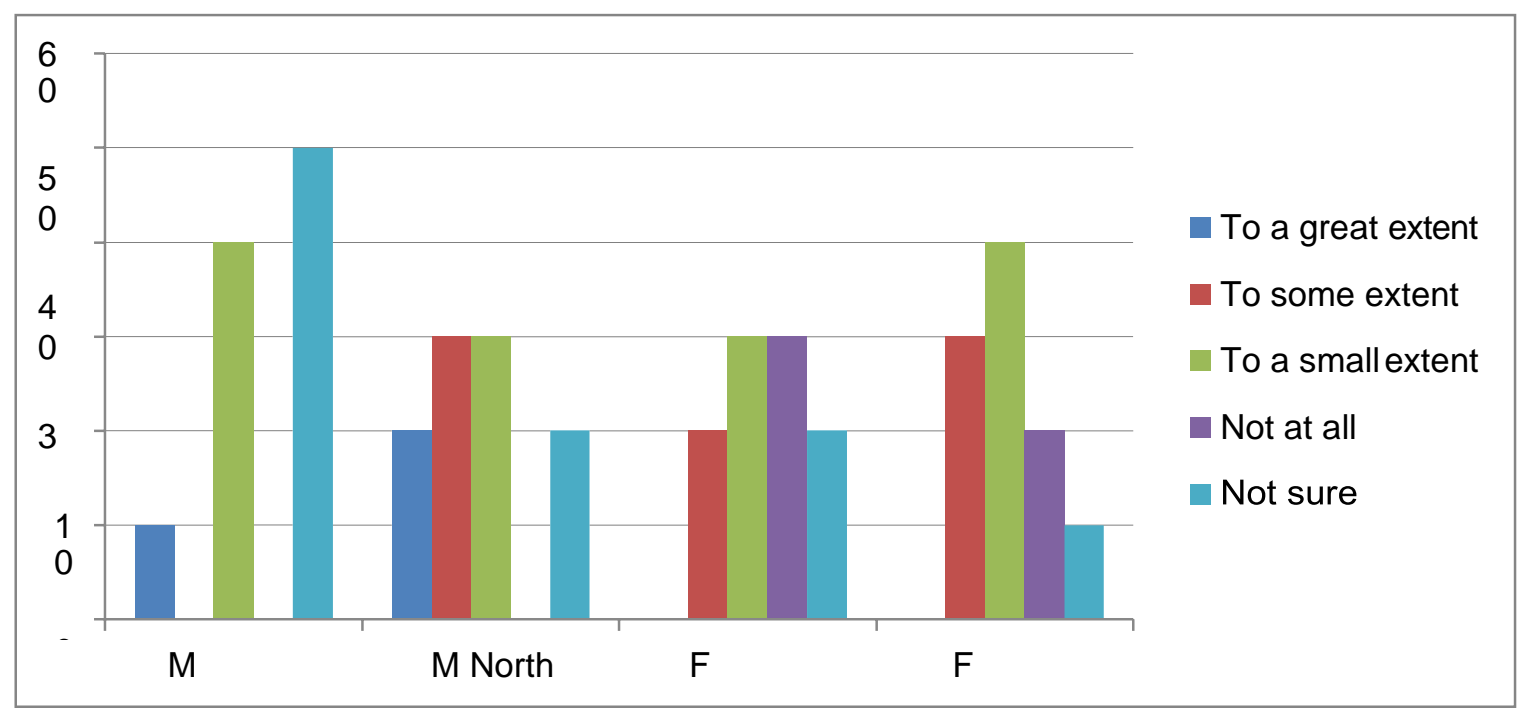

\section{Figure 15}

Ten percent of male teachers from center and 20\% from north region had opinion as activities in textbook did provide an opportunity to learners to interact with each other in English to a great extent while female teachers did not opt for this option. $30 \%$ of male teachers from north, $20 \%$ of female teachers from center and $30 \%$ from north region said it was so to some extent. $40 \%$ of male teachers from center, $30 \%$ from north, and $30 \%$ of female teachers from center and $40 \%$ from north region believed it was so to a small extent. $30 \%$ of female teachers from center and $20 \%$ from north region said it was not so at all. $50 \%$ of male teachers from center, $20 \%$ from north, $20 \%$ of female teachers from center and $10 \%$ from north region said they were not sure about this.

Statement 16. To what extent does the textbook promote active participation of the learners?

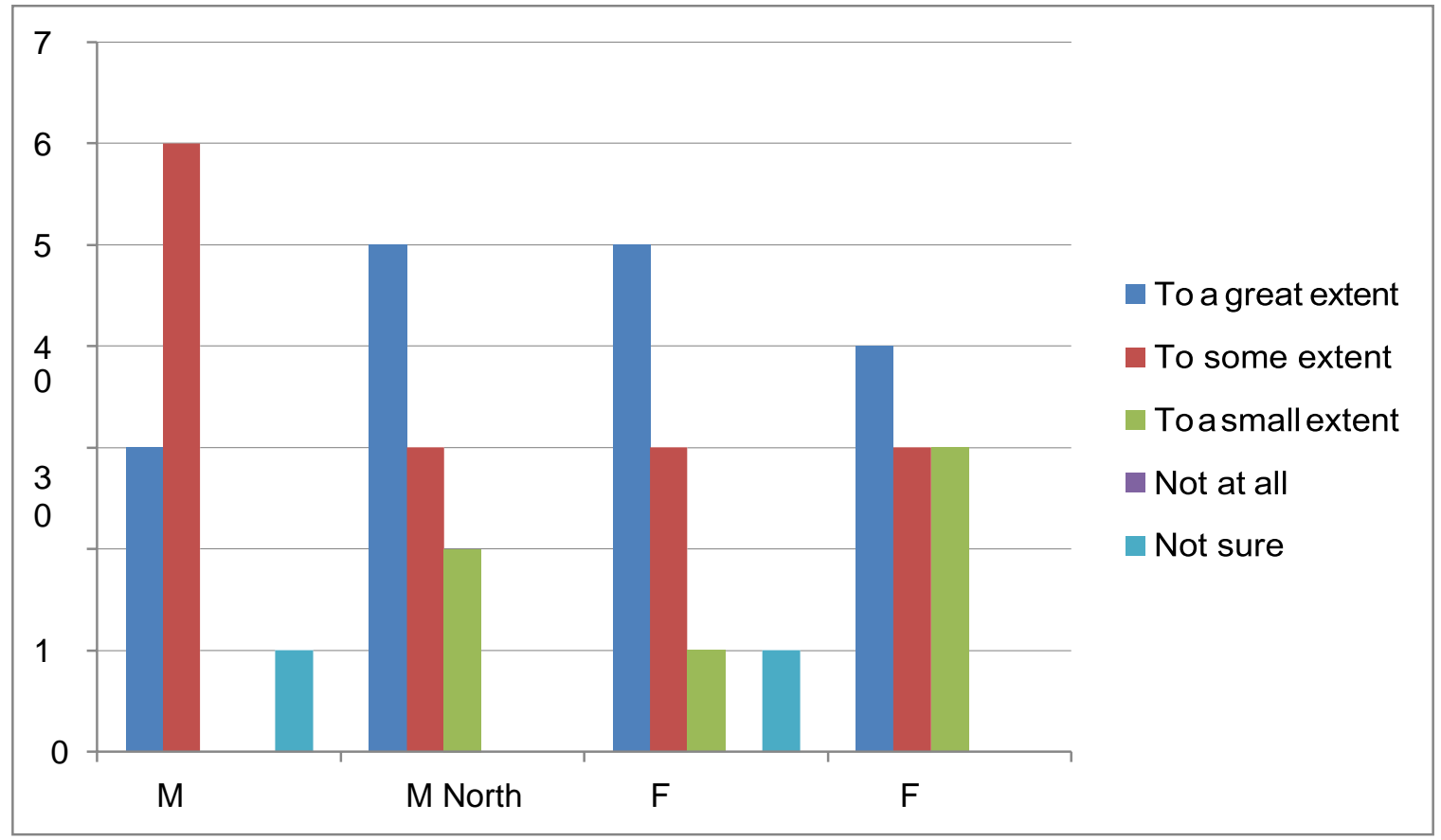




\section{Figure 16}

Above data reveals that $30 \%$ of male teachers from center, $50 \%$ from north, $50 \%$ of the female teachers from center and $40 \%$ from north region are of the opinion that textbook promote active participation of the learners to a great extent. $60 \%$ of male teachers from center, $30 \%$ from north, $30 \%$ of female teachers from center and north region each said it was so to some extent. $20 \%$ of male teachers from north, $10 \%$ of female teachers from center and 30\% from north region said it was so to a small extent. 10\% of male and female teachers each from center region were not sure about this.

Statement 17. To what extent does the textbook fulfill the objectives of the curriculum?

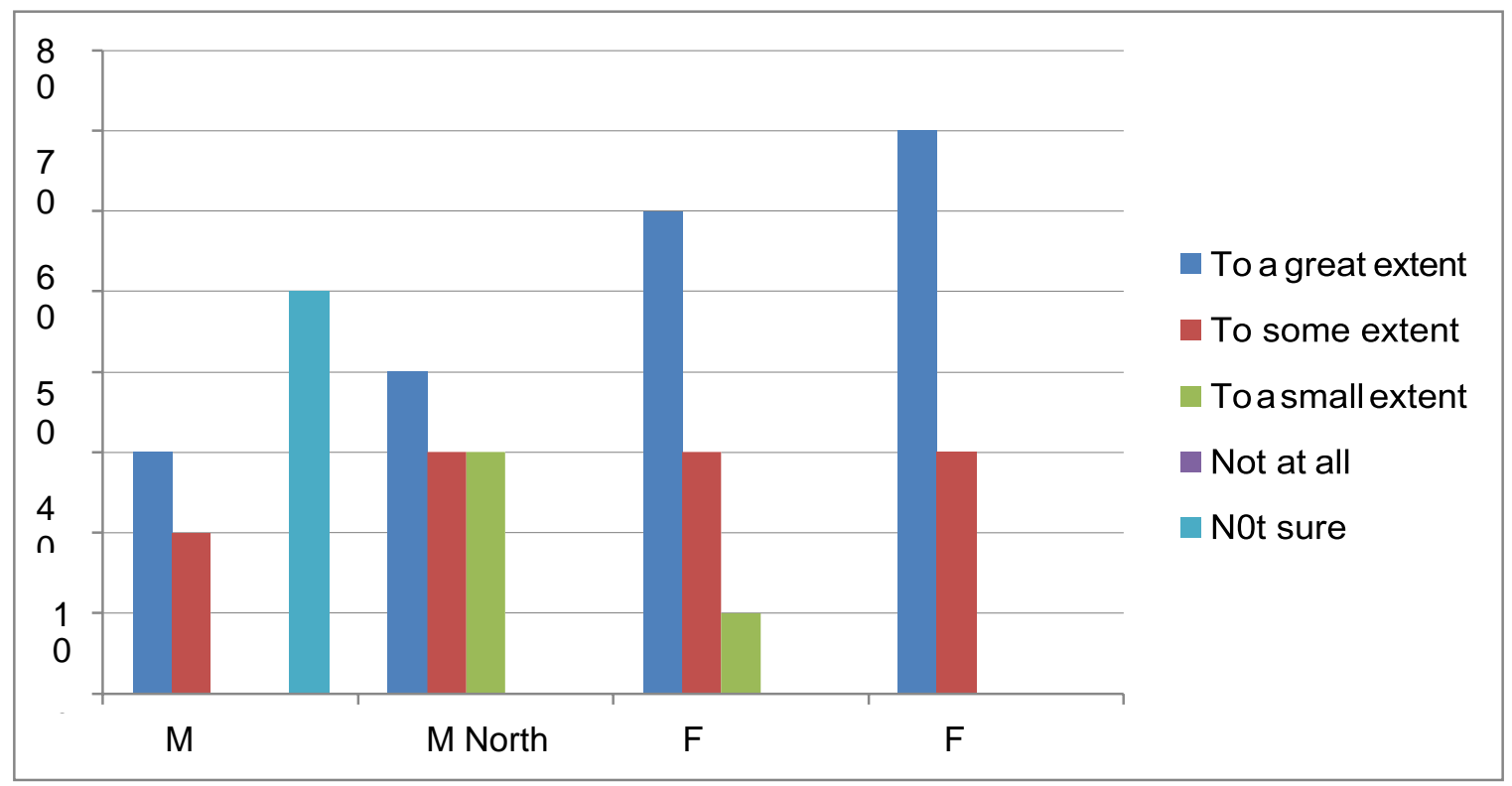

\section{Figure 17}

Thirty percent of male teachers from center, $40 \%$ from north, $60 \%$ of female teachers from center and $70 \%$ from north region believed that textbook fulfilled objectives of the curriculum to a great extent. $20 \%$ of male teachers from center, $30 \%$ each of male teachers from north, female teachers from centerand north regions said that it was so to some extent. $30 \%$ of male teachers from north and $10 \%$ of female teachers from center regions said it was so to a small extent where as $50 \%$ of male teachers from center region say they are not sure about this.

\section{Discussion}

Textbook evaluation in Pakistan as well as internationally is an on -going activity to ensure the availability of quality textbooks. In the present study reflective course book evaluation was attempted to measure its capacity in terms of learners' speech proficiency. Teachers' perspective was taken in to account to decide on the quality of the textbook as oral communicative competence development tool.

This study is in line with the work of Singay in Nepal (2018), who investigated the spoken language needs in English from the perspective of students and teachers to improve students' communication ability. Similarly, Zhang (2017) conducted an evaluation of course book in China to see how it impacts learners' academic progress. Harbi (2017) also evaluated EFL textbook for secondary stage in Saudi Public schools. Another similar attempt was made by Handayani (2016), who evaluated the textbook used for grade VII in Indonesia. Abdul Rehman (et al., 2016) aimed to identify and enhance the speaking skills of Ajloun National University students in Jordan. Furthermore, Zohrabi, Sabouri, \& Behroozian (2012) by taking in to 
consideration the perception of teachers and students evaluated the English textbook for high school in Iran and reported that textbook was grammar oriented and more emphasis was placed on reading more than three other skills. This overview of the past studies on textbook evaluation, bring forth more or less the same findings as proposed by the present research.

\section{Conclusion and Recommendations}

English language textbook is a major and the only tool being used in Pakistani public school classrooms, so this textbook should facilitate language acquisition and serve the purpose of OCC development. The results of study reflect that the present textbook does not match with the distinct needs of the learners to enable them to be proficient in their oral production, and importantly develop their oral communicative competence. The prescribed textbook is required to be accompanied by audio and video support for adequate target language exposure. The textbook needs to incorporate more of interactive activities for generating target language, and providing opportunities to the learners to stretch their utterances at discourse level effectively. Any resource material can produce better results if the teachers use it effectively. To upgrade teachers' knowledge and pedagogy, pre and in-service trainings should be conducted. It is imperative, therefore, to include teachers in the evaluation process to identify issues related to its effectiveness and suggesting strategies for improvement.

In this regard, Punjab Textbook and Curriculum Development Board must devise a criterion for assessment of textbooks to ensure quality textbooks, and it should be shared with teachers. It is imperative, therefore, to include teachers in the evaluation process to identify issues related to its effectiveness and suggesting strategies for improvement

\section{References}

Abdul, R. A. E., Mahmoud, A. A. S., \& Samer, M. A. Z. (2016). Improving English Language Speaking Skills of Ajloun National University Students. International Journal of English and Education.ISSN: 2278-4012, Vol.5, Issue:3.

Bachman, L. F \& Palmer, A. S. (1996). Language Testing in practice: designing and developing useful language tests, New York: Oxford University Press.

Bryman, A. (2008). Social research methods, Oxford, oxford University press.

Campbell, R., \& Wales, R. (1970). The study of Language Acquisition. In L. John (Ed.), New Horizons in Linguistics. United Kingdom, Penguin Books.

Canale, M., \& Swain, M. (1980). Theoretical bases of communicative approaches to second language teaching and testing .Applied Linguistics, 1(1), 1-Retrieved from 47.https://www.researchgate.net/...Swain/...Theoretical_Bases_of Communicative_Appro...

Cohen, L. Manion, L. \& Morrison, K. (2011). Research methods in education (7th ed.) United Kingdom, Routledge.

Chomsky, N. (1965). Aspects of the theory of syntax. MIT Press, United Kingdom, Cambridge.

Derakhshan, A., Tahery, F., \& Mirarab, N. (2015). Helping adult and young learner to communicate in 
speaking classes with confidence. Mediterranean Journal of Social Science, 6(2), 520-525.

Retrieved from http://dx.doi.org/10.5901/mjss.2015.v6n2p520

Dornyei, Z., \& Thurrell (1991). Strategic Competence and How to Teach It. ELT Journal, 45,

1623.Retrieved from http://dx.doi.org/10.1093/elt/45.1.16

Handayani, S. (2016). The Evaluation Of English Textbook For Grade VII Of Junior High School in Indonesia. (Doctoral dissertation) Retrieved from ejournal.unp.ac.id/index.php/selt/article/download/6993/5527

Harbi, M. A. A. (2017). Evaluation Study for Secondary Stage EFL Textbook: EFL Teachers' Perspectives. English Language Teaching; Vol. 10, No. 3; .doi: 10.5539/elt.v10n3p26 Retrieved from http://dx.doi.org/10.5539/elt.v10n3p26

Hymes, D. (1972). On communicative Competence in J.B. Pride \& J.Homes (Eds), Sociolinguistics: selected readings (pp.269-293). Harmondsworth, Penguin. Retrieved from wwwhomes.unibielefeld.de/sgramley/Hymes-1.pdf

Kumar, R. (2010). Research Methodology: A Step-by-Step Guide for Beginners. United Kingdom, Sage Publications.

Lee, S. M. (2013). The development of evaluation theories for foreign language textbooks. Journal of Pan-Pacific Association of Applied Linguistics, 17(2), 69-89. Retrieved fromfiles.eric.ed.gov/fulltext/EJ1014790.pdf

Mackey, A., \& Gass, S. M. (2007). Data elicitation for second and foreign language research. New Jersy: Lawrence and Erlbaum Associates, Inc. Publishers.

Singay (2018). English Oral Communication Needs of Bhutanese Students: As Perceived by the Teachers and Students. English Language Teaching; Vol 11, No. 4; 2018 ISSN 1916-4742 EISSN 1916-4750

Saleh, E. S. (2013). Understanding Communicative Competence. University Bulletin Vol. 3 ISSUE No.15 Retrieved from bulletin.zu.edu.ly/issue_n15_3/Contents/E_07.pdf

Stein, A., Malmberg, L. E. L., Each, P., Barnes, J., \& Sylvia, K. (2012). The influence of different forms of early childcare on children's emotional and behavioral development at school entry. Child: Care, Health and Development. Vol 39, 4, pp676-687 Retrieved from https://doi.org/10.1111/j.1365-2214.2012.01421 
Walliman, N. (2016). Social Research Methods: the essentials (2nded). NY: Sage Publications.

Zhang, X. (2017). A critical review of literature on English language teaching textbook evaluation: What systemic functional linguistics can offer? Journal of Language and Cultural Education, 5(1), ISSN -1339-4584.DOI: 10.1515/jolace-2017 -0005

Zohrabi, M., Sabouri, H., \& Behroozian, R. (2012). An Evaluation of Merits and Demerits of Iranian First Year High School English Textbook. English Language Teaching. English Language Teaching; Vol. 5, No. 8. ISSN 1916-4742 E-ISSN 1916-4750 14. doi:10.5539/eltv5n8p14. Retrieved from: http://dx.doi.org/10.5539/elt.v5n8p14 